\title{
Clinicopathological significance and prognosis of long noncoding RNA SNHG16 expression in human cancers: a meta- analysis
}

Ruonan Jiao, Wei Jiang, Xin Wei, Mengpei Zhang, Si Zhao and Guangming Huang ${ }^{*}$ (1)

\begin{abstract}
Background: Recent studies have highlighted the important role of long non-coding RNA SNHG16 in various human cancers. Here, we conducted a meta-analysis to investigate the effect of SNHG16 expression on clinicopathological features and prognosis in patients with different kinds of human cancers.

Methods: We performed a systematic search in electronic databases including PubMed, EMBASE, Cochrane Library and Web of Science, to investigate the potential association between SNHG16 expression and prognostic significance and clinical features in cancer patients. Odds ratios (ORs) or hazards ratios (HRs) with corresponding 95\% confidence intervals ( $95 \%$ Cls) were pooled to estimate the prognosis value of SNHG16 by StataSE 15.0 software.

Results: A total of 16 eligible studies with 1299 patients were enrolled in our meta-analysis. The results revealed that increased expression level of SNHG16 was significantly associated with larger tumor size (OR: 3.357; 95\% Cl: 2.173-5.185; $P<0.001)$, advanced TNM stage (OR: 2.930; 95\% Cl: 1.522-5.640; $P=0.001)$ and poor histological grade (OR: 3.943; 95\% Cl: 1.955-7.952; $P<0.001)$, but not correlated with smoking status $(P=0.489)$, sex $(P=0.932)$, distant metastasis $(P=0.052)$, or lymph node metastasis $(P=0.155)$. Moreover, the pooled HR showed that elevated expression SNHG16 was associated with a significantly poorer overall survival (OS) (HR=1.866, 95\% Cl: 1.571-2.216, $P<0.001)$. For the set of cancer types, high expression of SNHG16 was significantly associated with shorter OS in patients with cancers of the urinary system (HR: 2.523, 95\% Cl:1.540-4.133; P<0.001), digestive system (HR: 2.406, 95\% Cl:1.556-3.721; P<0.001), and other cancers (including glioma and non-small cell lung cancer) (HR: 1.786, 95\% Cl:1.406-2.267; P <0.001).
\end{abstract}

Conclusions: LncRNA SNHG16 overexpression might serve as an unfavorable prognostic factor, which provides a basis for medical workers to evaluate the prognosis of patients and to help the decision-making process.

Keywords: Long noncoding RNA; SNHG16, Cancer, Prognosis, Meta-analysis

\footnotetext{
* Correspondence: hgmnjmu@hotmail.com

Medical Center for Digestive Diseases, the Second Affiliated Hospital of

Nanjing Medical University, Nanjing 210011, China
}

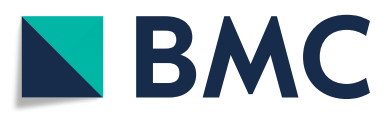

(c) The Author(s). 2020 Open Access This article is licensed under a Creative Commons Attribution 4.0 International License, which permits use, sharing, adaptation, distribution and reproduction in any medium or format, as long as you give appropriate credit to the original author(s) and the source, provide a link to the Creative Commons licence, and indicate if changes were made. The images or other third party material in this article are included in the article's Creative Commons licence, unless indicated otherwise in a credit line to the material. If material is not included in the article's Creative Commons licence and your intended use is not permitted by statutory regulation or exceeds the permitted use, you will need to obtain permission directly from the copyright holder. To view a copy of this licence, visit http://creativecommons.org/licenses/by/4.0/. The Creative Commons Public Domain Dedication waiver (http://creativecommons.org/publicdomain/zero/1.0/) applies to the data made available in this article, unless otherwise stated in a credit line to the data. 


\section{Background}

Cancer is a major disease that greatly endangers human health across the world. There were an estimated 14.1 million new cancer cases and 8.2 million cancer deaths globally in 2012 [1]. The incidence of cancer is increasing due to the growth and aging of the population, the intensification of industrialization and urbanization, and lifestyle modifications [1]. Thus, the burden of cancer cannot be ignored.

Mounting evidence has documented that dysregulation of tumor-suppressor genes and oncogenes is associated with human cancers [2]. However, little is known about the molecular and genetic mechanisms of tumors. Therefore, it is urgent to identify novel biomarkers for predicting the prognosis of patients with different types of cancer, which will improve their survival outcomes.

Long non-coding RNAs (lncRNAs) are composed of more than 200 nucleotides, but they do not encode proteins because they lack a recognizable open reading frame [3]. LncRNAs serve as guides, enhancers, scaffolds, or decoys by interacting with themselves or other signals in different pivotal physiological or pathological processes $[4,5]$. Recent studies have demonstrated that deregulated expression of lncRNAs plays an important role in cancer development and progression, and in the recurrence, metastasis, invasion, and growth of tumors [6-8]. Thus lncRNAs can be regarded as promising biomarkers for prognosis in various types of cancers.

Small nucleolar RNA host gene 16 (SNHG16) is a recently discovered lncRNA [9]. Recent studies have highlighted the important prognostic role of SNHG16 in various types of cancer, including bladder cancer $[10,11]$, cervical cancer [12], colorectal cancer [13], esophageal squamous cell carcinoma [14], gastric cancer [15], glioma [16], hepatocellular carcinoma [1719], non-small cell lung cancer [20], osteosarcoma [21, 22], ovarian cancer [23], pancreatic cancer [24], and papillary thyroid cancer [25]. Some studies have revealed that upregulated SNHG16 expression predicted poor prognosis for some cancers [26]. But some studies reported that overexpressing SNHG16 have tumor suppressing effect in some cancers, including hepatocellular carcinoma and acute lymphoblastic leukemia [27, 28]. Moreover, the expression level of SNHG16 is closely related to TNM stage, tumor size, histological grade, overall survival (OS), and other clinical attributes [17]. And SNHG16 participates in regulating the biological functions of tumor cells through complex regulatory mechanisms, such as cell proliferation, migration, invasion and apoptosis [29]. Therefore, we conducted a metaanalysis to investigate whether the lncRNA SNHG16 can be used as a prognostic biomarker for human cancers.

\section{Methods}

\section{Search strategies}

Electronic databases including PubMed, EMBASE, Cochrane Library, and Web of Science were searched. The search time was from the establishment of each database to June 20, 2019. The literature search terms included "Small nucleolar RNA host gene 16" or "SNHG16" or "Long non coding RNA SNHG16," and "cancer" or "carcinoma" or "tumor" or "neoplasm." The references of relevant literature were tracked for additional relevant studies.

\section{Literature inclusion and exclusion criteria}

After the literature search, two researchers independently assessed the literature. The inclusion and exclusion criteria are displayed in Table 1.

\section{Data extraction and quality assessment}

We recorded the following information: first author, publication date, country, cancer type, number of patients, sample type, sample detection method, cut-off value of SNHG16 expression level, clinical features mentioned above, HR and 95\% CI of OS. If HR and 95\% CI were provided in the study, we extracted them directly. If the relevant data were not reported, we extracted and analyzed data from Kaplan-Meier curves for OS according to the method described by Tierney [30]. Two investigators independently assessed the data, and when there were differences, a third researcher decided whether or not to include the study. Two researchers independently used the Newcastle-Ottawa Scale (NOS) to evaluate the

Table 1 Literature inclusion and exclusion criteria

$$
\begin{aligned}
& \text { Selection criteria } \\
& \text { Inclusion } \\
& \text { (1) Topic of study: human cancer } \\
& \text { (2) Diagnosis method: pathology or histology } \\
& \text { (3) Detected method of SNHG16: qRT-PCR, ISH, or other methods } \\
& \text { in tissues } \\
& \text { (4) Patients divided into "high SNHG16" and "low SNHG16" groups } \\
& \text { (5) Association between SNHG16 and clinicopathological and } \\
& \text { prognostic featuresa: clearly reported } \\
& \text { (6) HR and } 95 \% \text { Cls: acquired or estimated }
\end{aligned}
$$

\section{Exclusion}

(1) Literature type: reviews, case reports, meeting abstracts, and basic experimental research literature

(2) Duplicate articles or data

(3) Publication language: other than English

Abbreviations: $O S$ overall survival, $q R T-P C R$ quantitative reverse transcription polymerase chain reaction, $I S H$ in situ hybridization, $\mathrm{HR}$ hazard ratio, $95 \% \mathrm{CI}$ $95 \%$ confidence interval

${ }^{a}$ smoking status, sex, distant metastasis, lymph node metastasis, tumor number, tumor size, TNM stage, histological grade, and OS 
quality of the included studies. Literature with a score $\geq$ 6 were defined as high quality.

\section{Statistical analysis}

Meta-analysis was performed with StataSE15.0 (Stata Corporation). Heterogeneity tests were performed based on Cochran's $Q$ and Chi-square-based $I^{2}$ tests. If $P>$ $0.10, I^{2}<50 \%$ indicates that there is no significant heterogeneity in each study, and statistical analysis was performed using a fixed effects model; otherwise there was significant heterogeneity between the studies and a random effects model was used for the analysis. Subgroup analysis was used to explore sources of heterogeneity. The odds ratio (OR) and 95\% CIs were combined to assess the association of SNHG16 expression with clinicopathological parameters, and the $\mathrm{HR}$ and $95 \% \mathrm{CI}$ included in each study were combined to map the forest to evaluate the effect of SNHG16 expression on OS in human cancers. Publication bias was quantified using Begg's funnel plot and Egger's test. The reliability of the meta-analysis was tested by a sensitivity analysis. $P<$ 0.05 was considered statistically significant.

\section{Results}

\section{Data selection and basic characteristics}

A total of 145 articles were retrieved (PubMed $(n=40)$, EMBASE $(n=52)$, Cochrane Library $(n=0)$, and Web of Science $(n=53))$. According to the above-mentioned literature inclusion and exclusion criteria, 16 articles [10-25], consisting of 1299 patients, were finally included. The number of patients in the included studies ranged from 32 to 275 patients. All the research studies were from China. Twelve types of human cancers were included in the meta-analysis, including bladder cancer, cervical cancer, colorectal cancer, esophageal squamous cell carcinoma, gastric cancer, glioma, hepatocellular carcinoma, non-small cell lung cancer, osteosarcoma, ovarian cancer, pancreatic cancer, and papillary thyroid cancer. The expression level of SNHG16 was detected by using qRT-PCR in fifteen studies, and only one study used ISH. OS was reported in fourteen studies, and disease free survival (DFS) and progression free survival (PFS) were reported in only one study. Thus, OS was selected as the major survival outcome for our metaanalysis. HR was extracted directly in five studies and estimated from survival curves indirectly in the other 9 studies. The cut-off values for the expression level of SNGH16 were different in these studies, including the mean, median, and fold change compared with nontumor tissues, and in the study using ISH, strongly positive samples were defined as having high expression of SNGH16. The summary of screening results of the literature is shown in Table 2, and a flow chart describing the literature search and selection process is provided in Fig. 1.

\section{The association between SNHG16 expression and clinicalpathological features}

To demonstrate the clinical features of SNHG16 expression level in human cancers, we analyzed and summarized all the clinicopathological data from the included studies. As shown in Table 3, five studies composed of 373 patients revealed a significant association between SNGH16 overexpression and larger tumor size (OR: 3.357; 95\% CI: 2.173-5.185; $P<$ 0.001) using a fixed effects model, and no heterogeneity was found $\left(I^{2}=0 \% ; P=0.813\right)$. In eight studies including 591 patients, we found that overexpression of SNGH16 had a significant correlation with advanced TNM stage (OR: 2.930; 95\% CI: 1.522-5.640; $P=0.001$ ). A random effects model was performed for the analysis of TNM stage because of the heterogeneity $\left(I^{2}=64.200 \% ; P=0.007\right)$. A total of three studies including 187 patients reporting the relationship of SNGH16 expression with histological grade were analyzed. Our data demonstrated that elevated SNGH16 expression was associated with poor histological grade (OR: 3.943; 95\% CI: 1.955-7.952; $P<0.001$ ). Due to no heterogeneity $\left(I^{2}=13.800 \% ; P=0.313\right)$, a fixed effects model was used. However, no significant relationship between SNHG16 expression and smoking status, sex, distant metastasis and lymph node metastasis was found in the meta-analysis.

\section{The association between SNHG16 expression and overall survival}

As presented in Table 4 and Fig. 2, in total, 14 articles reporting the association between SNHG16 expression level and OS, including 1148 patients, were included in the meta-analysis. The results showed that high SNHG16 expression was significantly correlated with poor OS (HR: 1.866; 95\% CI: 1.571-2.216; $P<$ $0.001)$. There was no heterogeneity $\left(I^{2}=25.800 \% ; P=\right.$ $0.176)$ in the data, so a fixed effects model was used. In addition, subgroup analysis for extract method and detection method was performed. The subgroup analysis revealed that the extract method of HR, either the data in paper or survival curves, had a significant influence on OS (data in paper: HR: 2.912; 95\% CI: 1.729-4.906; $P<0.001$; survival curves: HR: 1.571 ; $95 \%$ CI: $1.155-2.135 ; P=0.004)$, and the heterogeneity results were $I^{2}=13.500 \%, \quad P=0.009, \quad I^{2}=2.260 \%, \quad P=$ 0.972 , respectively. For the detection method of SNHG16 expression, the overall HR for the qRT-PCR group for OS was 1.830 (95\% CI:1.538-2.177, $P<$ $0.001)$, with no heterogeneity $\left(I^{2}=20.200 \%, P=0.239\right)$. Compared with the group with a low expression level 
Table 2 Characteristics of included studies

\begin{tabular}{|c|c|c|c|c|c|c|c|c|c|}
\hline Study (year) & Country & $\begin{array}{l}\text { No. of } \\
\text { patient }\end{array}$ & Cancer type & Sample & Method & Cut-off & Outcome & $\begin{array}{l}\text { Extract } \\
\text { method }\end{array}$ & $\begin{array}{l}\text { NOS } \\
\text { score }\end{array}$ \\
\hline Cao (2018) [10] & China & 46 & Bladder cancer & Tissue & $\begin{array}{l}\text { qRT- } \\
\text { PCR }\end{array}$ & Mean & OS & $\begin{array}{l}\text { Survival } \\
\text { curves }\end{array}$ & 8 \\
\hline Peng (2019) [11] & China & 275 & Bladder cancer & Tissue & $\begin{array}{l}\text { qRT- } \\
\text { PCR }\end{array}$ & Mean & OS & Data in paper & 8 \\
\hline Zhu (2018) [12] & China & 38 & Cervical cancer & Tissue & $\begin{array}{l}\text { qRT- } \\
\text { PCR }\end{array}$ & - & OS & $\begin{array}{l}\text { Survival } \\
\text { curves }\end{array}$ & 6 \\
\hline Li $(2019)[13,26]$ & China & 56 & Colorectal cancer & Tissue & $\begin{array}{l}\text { qRT- } \\
\text { PCR }\end{array}$ & Median & OS & $\begin{array}{l}\text { Survival } \\
\text { curves }\end{array}$ & 8 \\
\hline $\operatorname{Han}(2018)$ [14] & China & 128 & $\begin{array}{l}\text { Esophageal squamous cell } \\
\text { carcinoma }\end{array}$ & Tissue & $\begin{array}{l}\text { qRT- } \\
\text { PCR }\end{array}$ & Median & OS & Data in paper & 8 \\
\hline $\begin{array}{l}\text { Wang (2019) [15, } \\
\text { 22] }\end{array}$ & China & 32 & Gastric cancer & Tissue & $\begin{array}{l}\text { qRT- } \\
\text { PCR }\end{array}$ & Median & OS & $\begin{array}{l}\text { Survival } \\
\text { curves }\end{array}$ & 8 \\
\hline Lu (2018) [16] & China & 48 & Glioma & Tissue & $\begin{array}{l}\text { qRT- } \\
\text { PCR }\end{array}$ & Median & OS PFS & Data in paper & 7 \\
\hline Ye (2019) [17] & China & 103 & Hepatocellular carcinoma & Tissue & $\begin{array}{l}\text { qRT- } \\
\text { PCR }\end{array}$ & Mean & - & - & 6 \\
\hline Guo (2019) [18] & China & 61 & Hepatocellular carcinoma & Tissue & $\mathrm{ISH}$ & - & OS & Data in paper & 6 \\
\hline Lin (2019) [19] & China & 88 & Hepatocellular carcinoma & Tissue & $\begin{array}{l}\text { qRT- } \\
\text { PCR }\end{array}$ & Mean & OS & $\begin{array}{l}\text { Survival } \\
\text { curves }\end{array}$ & 8 \\
\hline Han (2018) [14] & China & 66 & Non-small cell lung cancer & Tissue & $\begin{array}{l}\text { qRT- } \\
\text { PCR }\end{array}$ & Median & OS DFS & Data in paper & 8 \\
\hline Liao (2019) [21] & China & 96 & Osteosarcoma & Tissue & $\begin{array}{l}\text { qRT- } \\
\text { PCR }\end{array}$ & Mean & OS & $\begin{array}{l}\text { Survival } \\
\text { curves }\end{array}$ & 7 \\
\hline $\begin{array}{l}\text { Wang (2019) [15, } \\
\text { 22] }\end{array}$ & China & 65 & Osteosarcoma & Tissue & $\begin{array}{l}\text { qRT- } \\
\text { PCR }\end{array}$ & Median & OS & $\begin{array}{l}\text { Survival } \\
\text { curves }\end{array}$ & 7 \\
\hline Yang (2018) [23] & China & 103 & Ovarian cancer & Tissue & $\begin{array}{l}\text { qRT- } \\
\text { PCR }\end{array}$ & - & OS & $\begin{array}{l}\text { Survival } \\
\text { curves }\end{array}$ & 6 \\
\hline Liu (2019) [24] & China & 46 & Pancreatic cancer & Tissue & $\begin{array}{l}\text { qRT- } \\
\text { PCR }\end{array}$ & Median & OS & $\begin{array}{l}\text { Survival } \\
\text { curves }\end{array}$ & 8 \\
\hline Wen (2019) [25] & China & 48 & Papillary thyroid cancer & Tissue & $\begin{array}{l}\text { qRT- } \\
\text { PCR }\end{array}$ & - & - & - & 6 \\
\hline
\end{tabular}

Abbreviations: OS overall survival, PFS progression free survival, DFS disease free survival, - not available, $q R T$ - $P C R$ quantitative reverse transcription polymerase chain reaction, ISH in situ hybridization, NOS Newcastle-Ottawa Scale

of SNHG16, upregulated SNHG16 showed a statistically significant decrease in OS. For the set of cancer types, high expression of SNHG16 was significantly associated with shorter OS in patients with cancers of the urinary system (HR: 2.523, 95\% CI:1.540-4.133; P <0.001), digestive system (HR: 2.406, 95\% CI:1.556-3.721; P < 0.001 ), and other cancers (including glioma and non-small cell lung cancer) (HR: 1.786, 95\% CI:1.406-2.267; P < $0.001)$. However, in terms of the reproductive system and musculoskeletal system, elevated SNHG16 expression was not predictive of unfavorable OS $(\mathrm{HR}=1.592,95 \% \mathrm{CI}$ : $0.948-2.674, P=0.079$; HR:1.274, 95\% CI: $0.727-2.233$, $P=0.398$, respectively). Besides other cancers, all of the above cancers showed little heterogeneity between them $\left(\mathrm{I}^{2}<50 \%, P>0.1\right)$. For other cancers, significant heterogeneity was found $\left(\mathrm{I}^{2}=87.9 \%, P=0.004\right)$ (Table 3$)$, which may be due to the differences between cancers of different systems.
The association between SNHG16 expression and disease free survival / progression free survival

As presented in Table 5, there is just one study providing data on DFS or PFS respectively. We couldn't make meta-analysis to pool the results. As shown in Table 5, Han et al. reported that high SNHG16 expression was significantly correlated with poor DFS (HR: 4.505; 95\% CI: 1.980-10.309; P <0.001). Lu et al. demonstrated that high SNHG16 expression was related with shorter PFS (HR:3.167; 95\% CI:1.552-6.231; $\mathrm{P}<0.021$ ).

\section{Sensitivity analysis}

To identify whether individual studies had an impact on OS, sensitivity analysis was performed. The results suggested that no single study affected the stability of the HR values, indicating that the results of this meta-analysis data are stable and reliable (Fig. 3a). 


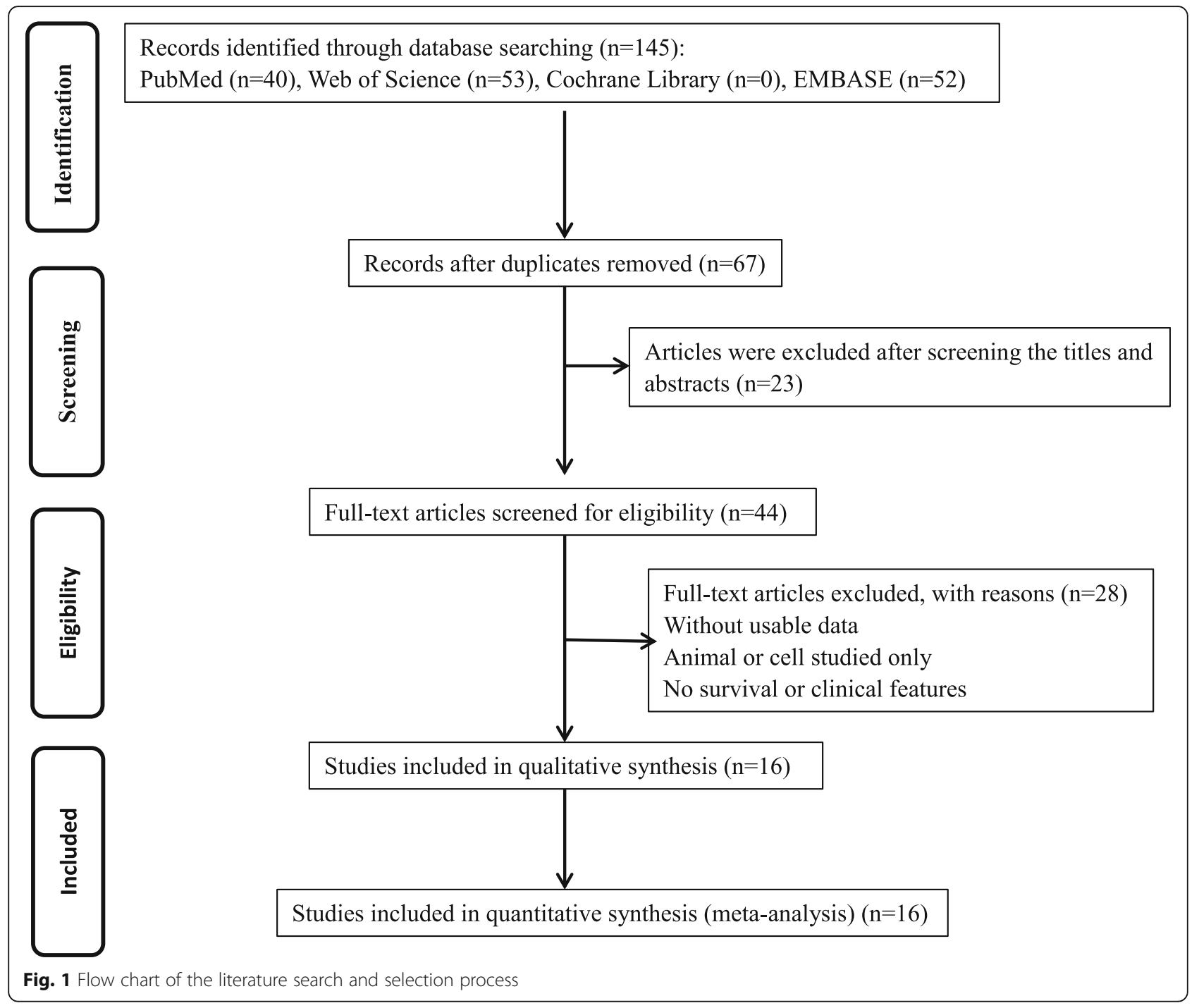

\section{Publication bias}

The potential publication bias of the meta-analysis was assessed by Begg's funnel plot and Egger's test. We observed that the shape of the funnel diagram was almost symmetrical and did not show any signs of significant asymmetry (Fig. 3b). As shown in Fig. 3b, there was no obvious publication bias for OS, as a result of the Begg' test $(P=0.584)$ and Egger's test $(P=0.234)$ (Table 6). Likewise, there was no obvious evidence for significant publication bias in terms of sex, lymph node metastasis,

Table 3 Meta-analysis of the studies reporting the association between over-expressed SNHG16 and clinicopathological parameters

\begin{tabular}{|c|c|c|c|c|c|c|c|c|}
\hline \multirow[t]{2}{*}{ Clinicopathological parameters } & \multirow[t]{2}{*}{ Studies } & \multirow[t]{2}{*}{ Patients } & \multirow[t]{2}{*}{ Model } & \multirow[t]{2}{*}{ OR $(95 \% \mathrm{Cl})$} & \multirow{2}{*}{$\begin{array}{l}P \\
\text { value }\end{array}$} & \multicolumn{3}{|c|}{ Heterogeneity } \\
\hline & & & & & & $\overline{P^{2}(\%)}$ & $x^{2}$ & $P$-value \\
\hline Smoking (yes vs no) & 4 & 296 & Fixed & $1.175(0.744-1.854)$ & 0.489 & 8.3 & 3.27 & 0.351 \\
\hline Sex (male vs female) & 12 & 1051 & Fixed & $1.286(0.766-1.277)$ & 0.932 & 0.0 & 5.05 & 0.929 \\
\hline Distant metastasis (yes vs no) & 5 & 362 & Random & $3.033(0.991-9.281)$ & 0.052 & 78.8 & 18.89 & 0.001 \\
\hline Lymph node metastasis (yes vs no) & 9 & 777 & Random & $1.923(0.781-4.735)$ & 0.155 & 83.8 & 49.38 & 0.000 \\
\hline Tumor number (multiple vs single) & 2 & 378 & Fixed & $0.829(0.531-1.293)$ & 0.409 & 0.0 & 0.01 & 0.910 \\
\hline Tumor size ( $\geq 5 \mathrm{~cm}$ vs $<5 \mathrm{~cm})$ & 5 & 373 & Fixed & $3.357(2.173-5.185)$ & 0 & 0.0 & 1.57 & 0.813 \\
\hline TNM stage (III/IV vs I/II) & 8 & 591 & Random & $2.930(1.522-5.640)$ & 0.001 & 64.2 & 19.58 & 0.007 \\
\hline Histological grade (poorly vs well/moderately) & 3 & 187 & Fixed & $3.943(1.955-7.952)$ & 0 & 13.8 & 2.32 & 0.313 \\
\hline
\end{tabular}


Table 4 Overall and subgroup analysis of SNHG16 for OS in human cancers

\begin{tabular}{|c|c|c|c|c|c|c|c|c|}
\hline \multirow[t]{2}{*}{ Variables } & \multirow[t]{2}{*}{ Studies } & \multirow[t]{2}{*}{ Patients } & \multirow[t]{2}{*}{ Model } & \multirow[t]{2}{*}{ HR (95\% Cl) } & \multirow[t]{2}{*}{$P$-value } & \multicolumn{3}{|c|}{ Heterogeneity } \\
\hline & & & & & & $\mathrm{I}^{2}(\%)$ & $x^{2}$ & $P$-value \\
\hline OS & 14 & 1148 & Fixed & $1.866(1.571-2.216)$ & 0.000 & 25.8 & 17.52 & 0.176 \\
\hline \multicolumn{9}{|l|}{ Extract method } \\
\hline Data in paper & 5 & 578 & Random & $2.912(1.729-4.906)$ & 0.000 & 70.40 & 13.5 & 0.009 \\
\hline Survival curves & 9 & 570 & Fixed & $1.571(1.155-2.135)$ & 0.004 & 0.00 & 2.26 & 0.972 \\
\hline \multicolumn{9}{|l|}{ Method } \\
\hline qRT-PCR & 13 & 1087 & Fixed & $1.830(1.538-2.177)$ & 0.000 & 20.2 & 15.04 & 0.239 \\
\hline ISH & 1 & 61 & - & $4.985(1.451-17.129)$ & 0.011 & - & - & - \\
\hline \multicolumn{9}{|l|}{ Cancer type } \\
\hline Urinary System & 2 & 321 & Fixed & $2.523(1.540-4.133)$ & 0.000 & 0.0 & 0.0 & 0.955 \\
\hline Digestive System & 6 & 411 & Fixed & $2.406(1.556-3.721)$ & 0.000 & 0.0 & 3.89 & 0.566 \\
\hline Reproductive system & 2 & 141 & Fixed & $1.592(0.948-2.674)$ & 0.079 & 0.0 & 0.32 & 0.575 \\
\hline Musculoskeletal system & 2 & 161 & Fixed & $1.274(0.727-2.233)$ & 0.398 & 0.0 & 0.01 & 0.910 \\
\hline Other & 2 & 114 & Fixed & $1.786(1.406-2.267)$ & 0.000 & 87.9 & 8.30 & 0.004 \\
\hline
\end{tabular}

Abbreviations: $H R$ hazard ratio, $95 \%$ Cl 95\% confidence interval, OS overall survival, $q R T-P C R$ quantitative reverse transcription polymerase chain reaction, ISH in situ hybridization

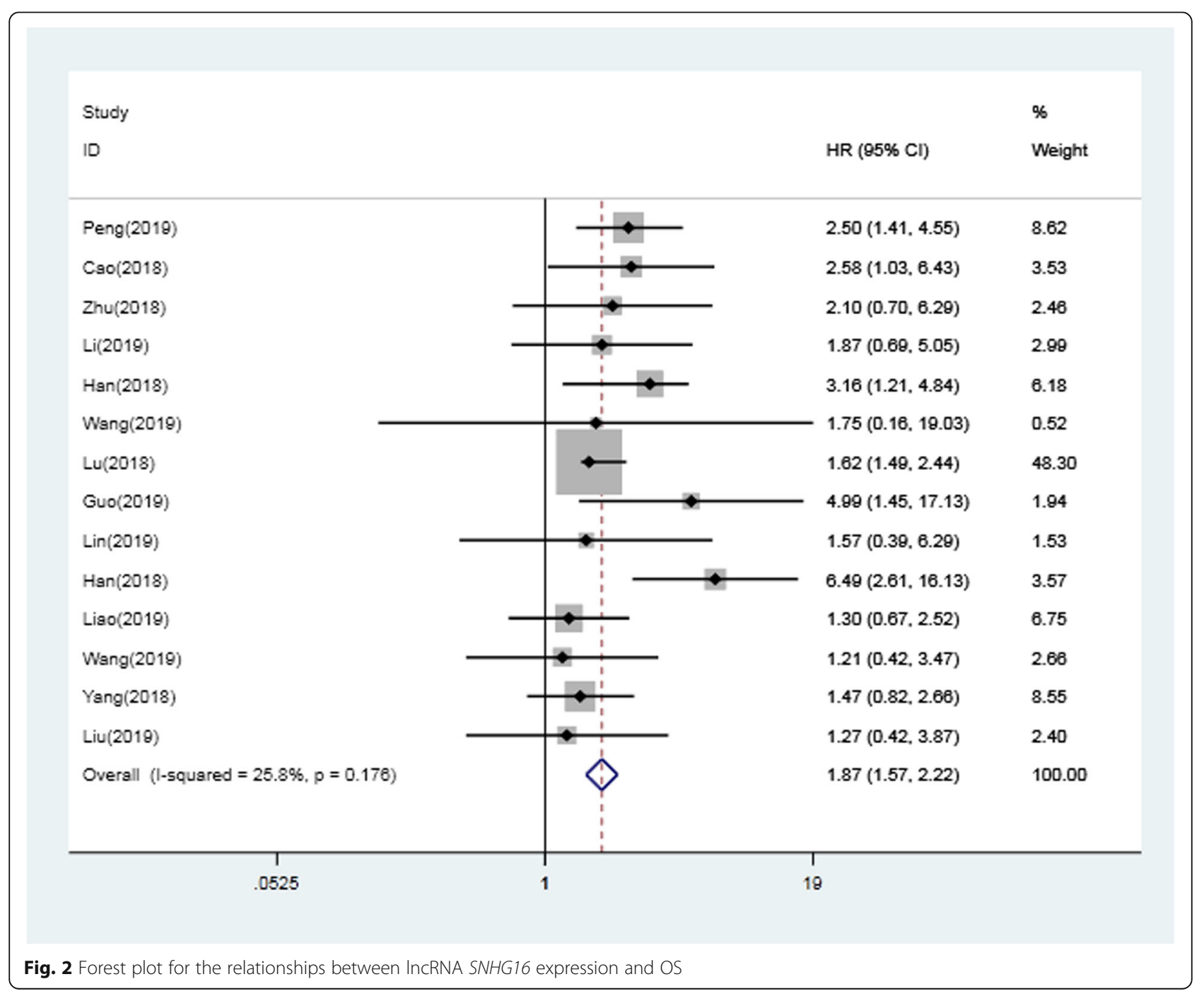


Table 5 The association between SNHG16 expression and DFS/PFS

\begin{tabular}{llllll}
\hline Study (year) & No. of patient & Cancer type & Outcome & HR $(95 \%$ Cl) & P \\
\hline Lu (2018) [16] & 48 & Glioma & PFS & $3.167(1.552-6.231)$ & 0.021 \\
Han (2018) [14] & 66 & Non-small cell lung cancer & DFS & $4.505(1.980-10.309)$ & $<0.001$ \\
\hline
\end{tabular}

Abbreviations: PFS progression free survival, DFS disease free survival, $H R$ hazard ratio, $95 \% \mathrm{Cl}$ 95\% confidence interval

or TNM stage (Table 6). We did not evaluate the publication bias for smoking, distant metastasis, tumor number, tumor size, and histological grade because the number of included studies was small.

\section{Discussion}

Many studies have found that IncRNAs play a crucial role in human cancers and inflammatory diseases by regulating different levels of gene expression programs, such as transcription, post-transcriptional processes, and epigenetics [31, 32].
LncRNAs are involved in various cellular events and act as guides, signals, decoys, and dynamic scaffolds by modulating cancer hallmarks, including DNA damage, metastasis, immune escape, cell stemness, drug resistance, metabolic reprogramming, and angiogenesis [33]. LncRNAs contribute to epigenetic changes where lncRNAs have the potential to act as oncogenes and/or tumor suppressors [29]. Thus lncRNAs take an important part in cancer development and growth. And the expression or functional abnormalities of lncRNA has been identified to be associated with tumor occurrence,

(a)

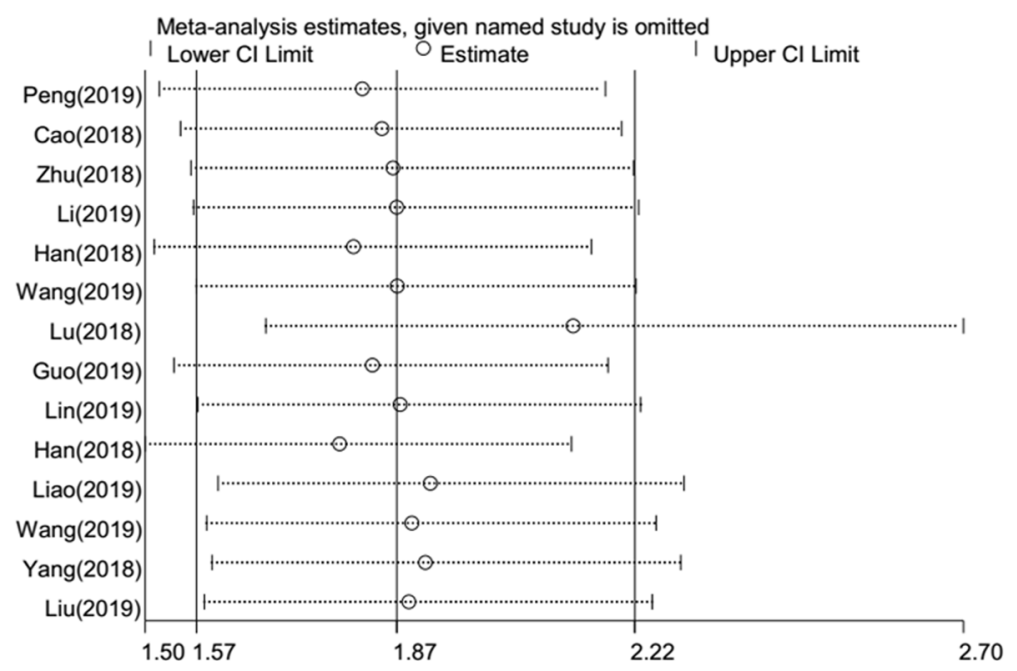

(b)

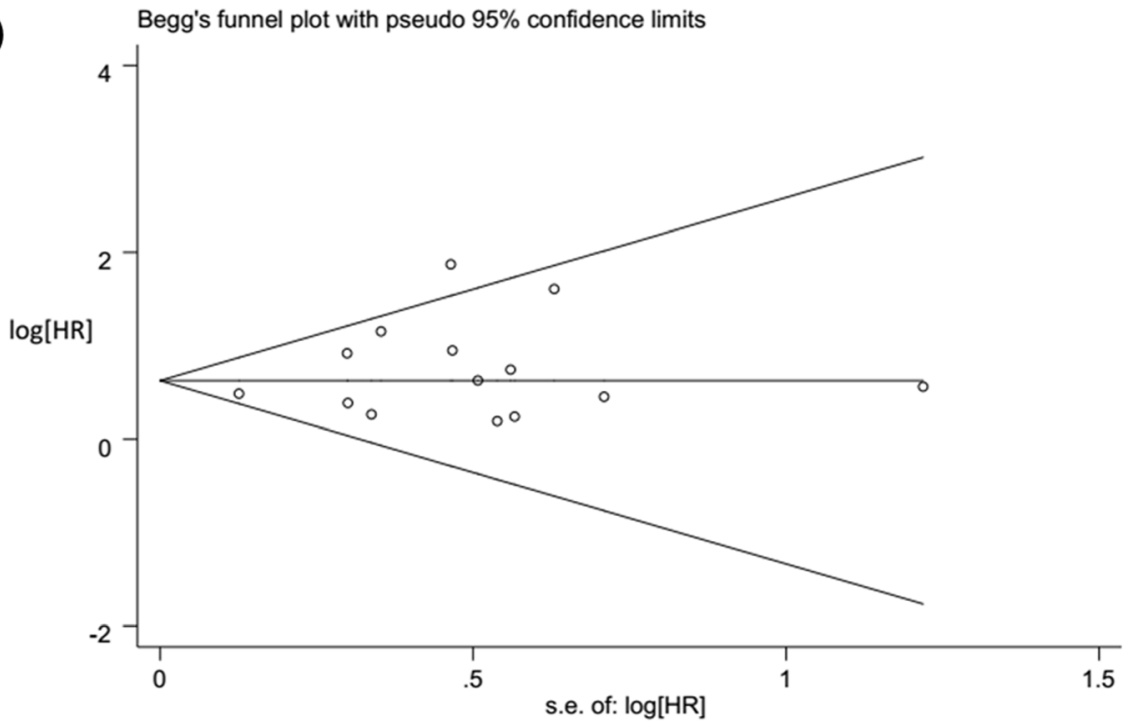

Fig. 3 Sensitivity analysis and publication bias for meta-analysis of SNHG16 and OS. a Sensitivity analysis for meta-analysis of SNHG16 and OS. b Funnel plot of the publication bias for OS 
Table 6 Publication bias of clinicopathological parameters by Begg's test and Egger's test

\begin{tabular}{lll}
\hline Clinicopathological parameters & Begg's test $(P)$ & Egger's test $(P)$ \\
\hline OS & 0.584 & 0.234 \\
Smoking (yes vs no) & - & - \\
Sex (male vs female) & 0.115 & 0.14 \\
Distant metastasis (yes vs no) & - & - \\
Lymph node metastasis (yes vs no) & 0.754 & 0.738 \\
Tumor number (multiple vs single) & - & - \\
Tumor size ( $\geq 5$ cm vs $<5$ cm) & - & - \\
TNM stage (III/IV vs I/II) & 0.711 & 0.604 \\
Histological grade (poorly vs well/moderately) & - & - \\
\hline
\end{tabular}

Abbreviations: OS overall survival

metastasis, progression and prognosis [34-36]. LncRNAs in general are thought to be promising as independent biomarkers for prognosis in human cancers [33].

The lncRNA SNHG16 has been reported as a modulator in multiple cancers. Research conducted by Cao et al. indicated that SNHG16 predicted poor prognosis, which can promote tumor proliferation by epigenetically silencing p21 in bladder cancer [10]. Meanwhile, SNHG16 contributes to sorafenib resistance by sponging miR-140-5p in hepatocellular carcinoma [17]. Christensen et al. found that SNHG16 was upregulated in colorectal cancer by affecting lipid metabolism [9]. Lian et al. reported that the expression of SNHG16 was significantly associated with invasion depth, lymph node metastasis, TNM stage, and histological differentiation in gastric cancer [37]. Several studies have shown that patients with elevated expression of SNHG16 had poor OS in comparison with those with low levels [10-16, 18-24]. Not only in cancer, recent evidence suggest that $S N H G 16$ also has a significant impact on regulating the inflammatory response. For example, SNHG16 can regulate LPS-induced inflammation injury in WI-38 cells by targeting miR-146a-5p/CCL5 [38].

This meta-analysis aimed to investigate the relationship between the expression level of SNHG16 and the pathological features in different types of human cancers. A total of 1299 patients from 16 studies were included. The fixed or random effect model was used for evaluating the smoking status, sex, distant metastasis, lymph node metastasis, tumor number, tumor size, TNM stage, and histological grade. We found that a high expression level of SNHG16 was correlated with larger tumor size, poor histological grade, and advanced TNM stage. Although elevated SNHG16 expression was associated with smoking status, high proportion of male, distant metastasis, and lymph node metastasis, there was no significant correlation. Furthermore, in terms of survival outcomes, patients with high expression of SNHG16 had significantly shorter OS than those with low SNHG16 expression.
When the association between lncRNA SNHG16 and tumor type was explored, we found that there was a significant relationship between SNHG16 overexpression and poor OS in patients with digestive system cancers, urinary system cancers, and other system cancers (including glioma and non-small cell lung cancer). However, regarding the reproductive system cancers and musculoskeletal system cancers, elevated SNHG16 expression was not predictive of unfavorable OS. In recent years, many studies have demonstrated that abnormal expression of SNHG16 does not only correspond to one tumor, but also can been detected different tumor tissues from various systems [39-41]. And the mechanisms of SNHG16 in different tumor types are unclear and controversial [29]. Results from this meta-analysis indicated that overexpression of the lncRNA SNHG16 might serve as a prognostic factor in patients with digestive system cancers, urinary system cancers, and other system cancers (including glioma and non-small cell lung cancer), which could provide a basis for medical workers to evaluate the prognosis of patients and to help the decision-making process.

There were limitations in this study: (1) All the included studies were from China, and the included literature was only published in English. The included literature may not be enough, there may be potential publication bias; (2) The number of patients and the number of studies in some analysis groups were relatively small, and not all types of human cancers were included; (3) The cut-off value for distinguishing high or low SNHG16 expression levels was not standard across all studies; (4) The detection method of SNHG16 expression was different among included studies, although most of them used qRT-PCR; (5) Not all the included studies reported the HRs and their 95\% CI directly, so we estimated them from survival curves, which may not be precise enough; and (6) The response to treatment of various cancer patients and the patients' different lifestyles may also underlie some of the heterogeneity. 


\section{Conclusion}

Overexpression of the lncRNA SNHG16 might serve as a prognostic factor, which provides a basis for medical workers to evaluate the prognosis of patients and to help the decision-making process. However, this metaanalysis has some limitations. In the future, multicenter, large-scale, and more comprehensive experimental research is still needed to verify the results of this meta-analysis.

\section{Abbreviations}

HR: Hazard ratio; 95\% Cl: 95\% confidence interval; qRT-PCR: Quantitative reverse transcription PCR; ISH: In situ hybridization; -: Not available; OS: Overall survival

\section{Acknowledgements}

We would like to thank the researchers and study participants for their contributions.

\section{Authors' contributions}

Idea and design: JR, HG. Data collection: WX, ZS, ZM. Data analysis: JR, JW, WX. Manuscript writing: JR. Manuscript revision: ZS, HG. All authors read and approved the version of the manuscript to be published. All authors take responsibility for appropriate content.

\section{Funding}

Not applicable.

\section{Availability of data and materials}

All data are included in this article.

\section{Ethics approval and consent to participate}

Not applicable.

\section{Consent for publication}

Not applicable.

\section{Competing interests}

The authors declare that they have no competing interests.

Received: 30 December 2019 Accepted: 7 July 2020

Published online: 16 July 2020

\section{References}

1. Torre LA, Bray F, Siegel RL, Ferlay J, Lortet-Tieulent J, Jemal A. Global cancer statistics, 2012. CA Cancer J Clin. 2015;65(2):87-108. https://doi.org/10.3322/ caac.21262 Torre, L. A.

2. Moses C, Garcia-Bloj B, Harvey AR, Blancafort P. Hallmarks of cancer: the CRISPR generation. Eur J Cancer. 2018;93:10-8. https://doi.org/10.1016/j.ejca. 2018.01.002.

3. Lee S, Kopp F, Chang TC, Sataluri A, Chen B, Sivakumar S, Yu H, Xie Y, Mendell JT. Noncoding RNA NORAD regulates genomic stability by sequestering PUMILIO proteins. Cell. 2016;164(1-2):69-80. https://doi.org/10. 1016/j.cell.2015.12.017

4. Yu WD, Wang H, He QF, Xu Y, Wang XC. Long noncoding RNAs in cancerimmunity cycle. J Cell Physiol. 2018;233(9):6518-23. https://doi.org/10.1002/ jcp.26568

5. Sanchez Calle A, Kawamura Y, Yamamoto Y, Takeshita F, Ochiya T. Emerging roles of long non-coding RNA in cancer. Cancer Sci. 2018;109(7):2093-100. https://doi.org/10.1111/cas.13642.

6. Xu T, Lin CM, Cheng SQ, Min J, Li L, Meng XM, Huang C, Zhang L, Deng ZY, Li J. Pathological bases and clinical impact of long noncoding RNAs in prostate cancer: a new budding star. Mol Cancer. 2018;17(1):103. https://doi. org/10.1186/s12943-018-0852-7.

7. Tang Y, He Y, Zhang P, Wang J, Fan C, Yang L, Xiong F, Zhang S, Gong Z, Nie $S$, et al. LncRNAs regulate the cytoskeleton and related rho/ROCK signaling in cancer metastasis. Mol Cancer. 2018;17(1):77. https://doi.org/10. 1186/s12943-018-0825-x
8. Sun C, Huang L, Li Z, Leng $K, X u$ Y, Jiang X, Cui Y. Long non-coding RNA MIAT in development and disease: a new player in an old game. J Biomed Sci. 2018;25(1):23. https://doi.org/10.1186/s12929-018-0427-3.

9. Christensen LL, True K, Hamilton MP, Nielsen MM, Damas ND, Damgaard CK, Ongen H, Dermitzakis E, Bramsen JB, Pedersen JS, et al. SNHG16 is regulated by the Wnt pathway in colorectal cancer and affects genes involved in lipid metabolism. Mol Oncol. 2016;10(8):1266-82. https://doi.org/10.1016/j. molonc.2016.06.003

10. Cao X, Xu J, Yue D. LncRNA-SNHG16 predicts poor prognosis and promotes tumor proliferation through epigenetically silencing p21 in bladder cancer. Cancer Gene Ther. 2018;25(1-2):10-7. https://doi.org/10.1038/s41417-0170006-X.

11. Peng $H, L i H$. The encouraging role of long noncoding RNA small nuclear RNA host gene 16 in epithelial-mesenchymal transition of bladder cancer via directly acting on miR-17-5p/metalloproteinases 3 axis. Mol Carcinog. 2019;58(8):1465-80. https://doi.org/10.1002/mc.23028.

12. Zhu H, Zeng Y, Zhou CC, Ye W. SNHG16/miR-216-5p/ZEB1 signal pathway contributes to the tumorigenesis of cervical cancer cells. Arch Biochem Biophys. 2018:637:1-8. https://doi.org/10.1016/j.abb.2017.11.003.

13. Li Y, Lu Y, Chen Y. Long non-coding RNA SNHG16 affects cell proliferation and predicts a poor prognosis in patients with colorectal cancer via sponging miR-200a-3p. Biosci Rep. 2019;39(5):BSR20182498. https://doi.org/ 10.1042/BSR20182498

14. Han GH, Lu KJ, Wang P, Ye J, Ye YY, Huang JX. LncRNA SNHG16 predicts poor prognosis in ESCC and promotes cell proliferation and invasion by regulating Wnt/beta-catenin signaling pathway. Eur Rev Med Pharmacol Sci. 2018;22(12):3795-803. https://doi.org/10.26355/ eurrev_201806_15262.

15. Wang X, Kan J, Han J, Zhang W, Bai L, Wu H. LncRNA SNHG16 functions as an oncogene by sponging MiR-135a and promotes JAK2/STAT3 signal pathway in gastric Cancer. J Cancer. 2019;10(4):1013-22. https://doi.org/10 7150/jca.29527.

16. Lu YF, Cai XL, Li ZZ, Lv J, Xiang YA, Chen JJ, Chen WJ, Sun WY, Liu XM, Chen JB. LncRNA SNHG16 functions as an oncogene by sponging MiR-4518 and up-regulating PRMT5 expression in Glioma. Cell Physiol Biochem. 2018; 45(5):1975-85. https://doi.org/10.1159/000487974.

17. Ye J, Zhang R, Du X, Chai W, Zhou Q. Long noncoding RNA SNHG16 induces sorafenib resistance in hepatocellular carcinoma cells through sponging miR-140-5p. Onco Targets Ther. 2019;12:415-22. https://doi.org/ 10.2147/OTT.S175176.

18. Guo Z, Zhang J, Fan L, Liu J, Yu H, Li X, Sun G. Long Noncoding RNA (IncRNA) Small Nucleolar RNA Host Gene 16 (SNHG16) Predicts Poor Prognosis and Sorafenib Resistance in Hepatocellular Carcinoma. Med Sci Monit. 2019;25:2079-86. https://doi.org/10.12659/MSM.915541.

19. Lin Q, Zheng $H$, Xu J, Zhang F, Pan H. LncRNA SNHG16 aggravates tumorigenesis and development of hepatocellular carcinoma by sponging miR-4500 and targeting STAT3. J Cell Biochem. 2019;120:11604-15. https:// doi.org/10.1002/jcb.28440.

20. Han W, Du X, Liu M, Wang J, Sun L, Li Y. Increased expression of long noncoding RNA SNHG16 correlates with tumor progression and poor prognosis in non-small cell lung cancer. Int J Biol Macromol. 2019;121:270-8. https:// doi.org/10.1016/j.ijbiomac.2018.10.004

21. Liao $S$, Xing $S, M a$ Y. LncRNA SNHG16 sponges miR-98-5p to regulate cellular processes in osteosarcoma. Cancer Chemother Pharmacol. 2019; 83(6):1065-74. https://doi.org/10.1007/s00280-019-03822-5.

22. Wang $X$, Hu K, Chao Y, Wang L. LncRNA SNHG16 promotes proliferation, migration and invasion of osteosarcoma cells by targeting miR-1301/BCL9 axis. Biomed Pharmacother. 2019;114:108798. https://doi.org/10.1016/j. biopha.2019.108798.

23. Yang XS, Wang GX, Luo L. Long non-coding RNA SNHG16 promotes cell growth and metastasis in ovarian cancer. Eur Rev Med Pharmacol Sci. 2018; 22(3):616-22. https://doi.org/10.26355/eurrev_201802_14284.

24. Liu S, Zhang W, Liu K, Liu Y. LncRNA SNHG16 promotes tumor growth of pancreatic cancer by targeting miR-218-5p. Biomed Pharmacother. 2019; 114:108862. https://doi.org/10.1016/j.biopha.2019.108862.

25. Wen Q, Zhao L, Wang T, Lv N, Cheng X, Zhang G, Bai L. LncRNA SNHG16 drives proliferation and invasion of papillary thyroid cancer through modulation of miR-497. Onco Targets Ther. 2019;12:699-708. https://doi.org/ 10.2147/OTT.S186923.

26. Li J, Gao C, Liu C, Zhou C, Ma X, Li H, Li J, Wang X, Qi L, Yao Y, et al. Four IncRNAs associated with breast cancer prognosis identified by coexpression 
network analysis. J Cell Physiol. 2019;234(8):14019-30. https://doi.org/10. 1002/jcp.28089.

27. Yang TX, Jin X, Lan JP, Wang WS. Long non-coding RNA SNHG16 has tumor suppressing effect in acute lymphoblastic leukemia by inverse interaction on hsa-miR-124-3p. IUBMB Life. 2019;71(1):134-42. https://doi.org/10.1002/ iub.1947.

28. Xu FF, Guoqing Zha GQ, Wu YP, Cai WL, Ao J. Overexpressing IncRNA SNHG16 inhibited HCC proliferation and chemoresistance by functionally sponging hsa-mir-93. Onco Targets Ther. 2018;11:8855-63. https://doi.org/ 10.2147/OTT.S182005.

29. Yang M, Wei W. SNHG16: a novel long-non coding RNA in human cancers. Onco Targets Ther. 2019;12:11679-90. https://doi.org/10.2147/OTT.S231630.

30. Tierney JF, Stewart LA, Ghersi D, Burdett S, Sydes MR. Practical methods for incorporating summary time-to-event data into meta-analysis. Trials. 2007;8: 16. https://doi.org/10.1186/1745-6215-8-16.

31. Adams BD, Parsons C, Walker L, Zhang WC, Slack FJ. Targeting noncoding RNAs in disease. J Clin Invest. 2017;127(3):761-71. https://doi.org/10.1172/ $\mathrm{JCl} 84424$.

32. Chandra Gupta S, Nandan TY. Potential of long non-coding RNAs in cancer patients: from biomarkers to therapeutic targets. Int J Cancer. 2017;140(9): 1955-67. https://doi.org/10.1002/ijc.30546.

33. Maggie MB, Aaron MJ. Exploring the mechanisms behind long Noncoding RNAs and Cancer. Noncoding RNA Res. 2018;3(3):108-17. https://doi.org/10. 1016/..ncrna.2018.03.001.

34. Yuan L, Xu ZY, Ruan SM, Mo SW, Qin JJ, Cheng XD. Long non-coding RNAs towards precision medicine in gastric Cancer: early diagnosis, treatment, and drug resistance. Mol Cancer. 2020;19(1):96. https://doi.org/10.1186/ s12943-020-01219-0.

35. Jin KT, Yao JY, Fang XL, Di H, Ma YY. Roles of IncRNAs in Cancer: focusing on angiogenesis. Life Sci. 2020;252:117647. https://doi.org/10.1016/j.lfs.2020. 117647

36. Wang YJ, Sun BS, Wen $X$, Hao D, Du D, He G, Jiang X. The roles of IncRNA in cutaneous squamous cell carcinoma. Front Oncol. 2020;10:158. https:// doi.org/10.3389/fonc.2020.00158.

37. Lian D, Amin B, Du D, Yan W. Enhanced expression of the long non-coding RNA SNHG16 contributes to gastric cancer progression and metastasis. Cancer Biomark. 2017;21(1):151-60. https://doi.org/10.3233/CBM-170462

38. Zhou Z, Zhu Y, Gao G, Zhang Y. Long noncoding RNA SNHG16 targets miR146a-5p/CCL5 to regulate LPS-induced WI-38 cell apoptosis and inflammation in acute pneumonia. Life Sci. 2019;228:189-97. https://doi.org/ 10.1016/.lff.2019.05.008.

39. Gong CY. Tang R, Nan W, Zhou KS4, Zhang HH. Role of SNHG16 in human cancers. Clin Chim Acta. 2020;503:175-80. https://doi.org/10.1016/j.cca.2019. 12.023.

40. Chen H, Li M, Huang P. LncRNA SNHG16 promotes hepatocellular carcinoma proliferation, migration and invasion by regulating miR-186 expression. J Cancer. 2019;10(15):3571-81. https://doi.org/10.7150/jca.28428.

41. Xu C, Hu C, Wang Y, Liu S. Long Noncoding RNA SNHG16 promotes human retinoblastoma progression via sponging miR-140-5p. Biomed Pharmacother. 2019;117:109153. https://doi.org/10.1016/j.biopha.2019. 109153.

\section{Publisher's Note}

Springer Nature remains neutral with regard to jurisdictional claims in published maps and institutional affiliations.

Ready to submit your research? Choose BMC and benefit from:

- fast, convenient online submission

- thorough peer review by experienced researchers in your field

- rapid publication on acceptance

- support for research data, including large and complex data types

- gold Open Access which fosters wider collaboration and increased citations

- maximum visibility for your research: over $100 \mathrm{M}$ website views per year

At BMC, research is always in progress.

Learn more biomedcentral.com/submissions 